\title{
Legionella risk assessment in cruise ships and ferries
}

\author{
Pasqualina Laganà', Maria Elsa Gambuzza², Santi Delia' \\ ${ }^{1}$ Department of Biomedical and Dental Sciences and Morphofunctional Imaging, University of Messina, Italy \\ ${ }^{2}$ Ministry of Health, USMAF, Territorial Office of Messina, Sicily, Italy
}

Pasqualina Laganà, Maria Elsa Gambuzza, Santi Delia. Legionella risk assessment in cruise ships and ferries. Ann Agric Environ Med. 2017; 24(2): 276-282. https://doi.org/10.26444/aaem/74717

\begin{abstract}
Introduction. The increasing development of marine traffic has led to a rise in the incidence of legionellosis among travellers. It occurs in similar environments, especially closed and crowded, and aboard ships Legionella survives and multiplies easily in water pipes, spreading into the environment through air conditioning systems and water distribution points. Although in recent years in the construction of cruise ships preventive measures aimed at curbing the proliferation of Legionella (design, materials, focus on the operation and maintenance of the water system), have been taken account, little or no attention has been paid to small ships which, in many cases, are old and not well maintained.

Objective. The aim of the study was to evaluate the frequency and severity of Legionella contamination in ferries and cruise ships in order to adopt more specific control measures.

Materials and method. A prevalence study was carried out on 10 ferries and 6 cruise ships docking or in transit across the port of Messina (Sicily, Italy). Water and air samples collected from many critical points were tested for qualitative and quantitative identification of Legionella.

Results and conclusions. Legionella pneumophila sg 1 was isolated from the samples of shower and tap water in 7 (70\%) of the 10 ferries examined, and in 3 (33\%) of the 6 cruise ships examined, and L. pneumophila sg 2-14 in 8 (80\%) and 1 (16.7\%) of these ships, respectively. No Legionella contamination was found in whirlpool baths, air and ice samples. In conclusion, the data obtained confirm higher levels of Legionella contamination in local ferries and cruise ships, underlining the need to adopt corrective actions more specific for these smaller vessels.
\end{abstract}

\section{Key words}

Legionella pneumophila, Cruise ships, Ferries, Preventive measures

\section{INTRODUCTION}

National and international maritime transport is very important in Italy and worldwide [1]. Tourism has played an important role in the economic growth of developed and developing countries, which also contributes to the increased traffic of cruise ships. In addition, ferries represent an important part of the public transport systems of many waterside cities and islands, since they carry primarily passengers as well as vehicles and cargo across bodies of water, linking many waterside cities and islands, allowing direct transit between different points. In Italy, a country with a total of almost $8,000 \mathrm{~km}$ of coastline, including the peninsula itself and numerous islands, there are many ferry services linking the islands by sea to the mainland. In addition, ships from countries around the Mediterranean are moored in the well-equipped Italian ports. Among the main Italian ports, Messina occupies an important place, since it represents the main departure port from Sicily to the Italian mainland and the Eolian islands. In particular, along the Strait of Messina, the body of water of about $3 \mathrm{~km}$ that separates Sicily from the rest of Italy, both international cruise and national ferry traffic are particularly intense every day, especially during the warmer months. In addition, Messina is included among the itineraries of major international cruise lines. Consequently, there is an increased risk for the acquisition of infectious

Address for correspondence: Pasqualina Laganà, Department of Biomedical and Dental Sciences and Morphofunctional Imaging, University of Messina, Italy E-mail: plagana@unime.it

Received: 16 July 2016; accepted: 10 April 2017; first published on June 2017 diseases frequently associated with both the international/ national marine traffic, and modern high-speed transport.

Outbreaks of measles, rubella, varicella, meningococcal meningitis, hepatitis A, legionellosis, and other respiratory and gastrointestinal illnesses, in addition to the most recently reported outbreaks of influenza and norovirus, occurred among the passengers and crews of ships [2]. Such outbreaks represent a serious hazard, not only for their potentially dangerous health consequences, but also for the high costs incurred by the industry. Among the different travel-related infectious diseases, legionellosis plays an important role. Legionellosis is a potentially fatal lung infection caused by the inhalation or possibly aspiration of warm, aerosolized water containing Legionella organisms. Until recently, it was thought to be a non-contagious disease, but recently there has been a report with evidence of a possible inter-human contagion [3].

The legionellosis alert and negative influence on tourism are witnessed by the increasing number of cases contracted on board cruise ships, so much so that, according to the CDC in Atlanta, USA, they represent $20 \%$ of the total [4]. The greatest danger for crew and cruise passengers is represented by the pools and whirlpool baths, as well as by the cabin showers and, potentially, all water points on board ships [5, $6,7,8,9,10,11,12,13,14]$.

Legionella grows readily in man-made biofilm formed inside plumbing fixtures and pipes where warm temperatures and the build-up of nutrients and microorganisms on surfaces provide an ideal environment, which are also populated by other microorganisms involved into a multitude of trophic interactions $[15,16,17,18]$. Several factors can contribute to the potential risk of infection: water contamination levels, 
host factors (older age, tobacco smoke, chronic degenerative diseases, state of immunodeficiency, etc.), and specific virulence factors that can often be enhanced by a protozoa - or amoeba - bacterium relationship [19]. Most cases of legionellosis are sporadic, but outbreaks can always occur, due to the contamination of hot and cold water systems, spa pools, natural pools, thermal springs, evaporative condensers and respiratory therapy equipment $[20,21,22]$. Biofilm formation can provide a further means for Legionella survival and dissemination [23, 24].

In the light of these considerations, the Regional Reference Laboratory for Clinical and Environmental Surveillance of Legionellosis, Messina branch, in collaboration with the Maritime Health Office in Messina, undertook an epidemiological survey on ferries and cruise ships, in order to assess the impact of Legionella spp. contamination in vessels. More specifically, this study assessed the frequency and severity of L. pneumophila contamination in cruise ships and ferries in order to evaluate both the risk exposure for crews and passengers belonging to these different categories of vessels. and the control measures adopted.

\section{MATERIALS AND METHOD}

The survey was carried out on 16 ships docked at the port of Messina, from March - October: 10 ferries, including 7 belonging to a national company and 3 to a local shipping company, linking the ports of Messina and Villa San Giovanni (Strait of Messina), in addition to 6 cruise ships belonging to national companies and temporarily docked at the port of Messina.

During the investigation, a very high number and types of sites were examined. In addition, due to the diversity of plumbing and mechanical systems used on the ships, in some cases more than one sample from the suspected source was collected. Any water source that might be aerosolized was considered a potential means for the transmission of Legionella, and was consequently analyzed.

Both water and air sampling were collected from many critical sites, including crew cabins, kitchens, coffee bars, rooms connected to the central air conditioning system, tanks, and hot baths.

On board all ships, the epidemiological investigation was divided in three phases.

Phase I - Visual inspection. A preliminary inspection was performed at all recreational and potable water points, according to the inspection outlines of the European Ships Manual for Hygiene Standard and Communicable Disease Surveillance on Passenger Ships [25]. Visual inspection criteria included cleanliness, water turbidity, wall slime, sludge, general repair, access, and location of the sampling points. Moreover, air outlets where air samples should be collected were identified.

Phase II - Delivery of a questionnaire. A questionnaire was given to the master of each ship to collect the following information:

- characteristics of the ship, mainly concerning the slips, the latest water supplies, etc.;

- recent crew and passenger respiratory diseases, or other infectious diseases;
- routine water pipes maintenance and repair;

- chemical water treatment and analytical tests carried out; - any suspected case of legionellosis.

\section{Phase III - Sampling and analysis (water and air).}

Water sampling. A high number of sites were tested in both ferries and in cruise ships. In addition, due to the diversity of plumbing and mechanical systems in use, in some cases more than one sample from the suspected source was collected. All water sources that might be aerosolized were considered a potential means for the transmission of Legionella and consequently analyzed.

Hot water samples were collected using $1 \mathrm{~L}$-sterile glass bottles, after flushing for 5-10 min and sterilization of the terminal portion of the tap. Sampling was carried out taking care not to neglect any part of the ship: stern, bow, starboard and port side, and each deck, to obtain a sampling representative of the hygienic-sanitary conditions.

Air sampling. As previously mentioned, at the main points considered at risk, active air sampling was performed by using Surface Air System (SAS 100, PBI International, Milan, Italy), located about $20 \mathrm{~cm}$ from the point of entry of conditioned air in the various premises. The SAS was set to aspirate $100 \mathrm{~L} / \mathrm{min}$, and aspirated for 10 minutes, for a total of $1,000 \mathrm{~L}$. A total of 64 samplings were carried out. The number of colonies present on each plate was calculated according to the conversion table provided by the manufacturer, and expressed in $\mathrm{cfu} / \mathrm{m}^{3}$.

Isolation and identification of Legionella spp. To isolate Legionella spp. from water samples, the standard procedures reported in the Italian Guidelines for the Prevention and Control of Legionellosis were used [26]. More specifically, 1 $\mathrm{L}$ water samples were concentrated to $10 \mathrm{~mL}$ through $0.2 \mu \mathrm{m}$ porosity membrane filters, and incubated at $50^{\circ} \mathrm{C}$ for $30 \mathrm{~min}$ in a thermostatic bath. Concentrated and unconcentrated samples were spread on duplicate plates of Buffered CharcoalYeast Extract (BCYE) Agar Base Medium (Oxoid, Ltd., Milan, Italy), incubated for 10 days at $36-37^{\circ} \mathrm{C}$ in a moist chamber with $2.5 \% \mathrm{CO}_{2}$. The suspected colonies were isolated and confirmed as Legionella spp. after screening their inability to grow on a culture medium without cysteine. Legionella spp. counts were reported in colony forming units/litre (CFU/L) according to the number of colonies per plate and to the dilutions performed on the original sample. The isolates were further identified as L. pneumophila serogroup 1, L. pneumophila serogroups 2-14, or Legionella spp using the microagglutination Legionella Latex Test Kit (Oxoid).

\section{STATISTICAL ANALYSIS}

The data obtained were processed using Microsoft Office Excel in order to produce graphics and tables.

\section{RESULTS}

From a total of 66 water samples collected from the showers in crew cabins, 32 (48\%) were positive for Legionella. In water coming from the taps of sinks located at various sites on the 
ships (including the WC inside the cabins of passengers and crew, bars, gyms, bridge, etc.), Legionella was isolated in 20 cases out of 46 (43\%). Legionella presence in 3 (23\%) of the 13 reservoirs controlled, was indexed as high risk, since from this point water branches in the pipes to the whole ship. Only 1 of $13(8 \%)$ samples of drinkable water (gushing fountain) was positive, but it has not yet been shown that Legionella is transmitted by ingestion of contaminated water. It is also true that to drink from the gushing fountains, they must be approach by the face which means inhaling droplets that could potentially be contaminated $[27,28]$.

No Legionella contamination was found in whirlpool baths, air and ice samples.

Among 92 water samples obtained from ferries, 59 (64\%) resulted positive for L. pneumophila, in contrast to cruise ships where $6(4 \%)$ of 136 water samples resulted positive (Tab. 1).

Detailed sampling plans were made on board the ferries and cruise ships, and the CFU/L range of the L. pneumophila 1 and 2-14 isolated also indicated (Tab. 1).

Figure 1(a) shows the percentage distribution of positive samples according to the source. Figure 1(b) shows the percentage of Legionella positive samples isolated from ferries (91\%), compared to cruise ships (9\%). Figure 1(c) shows the distribution percentages of serogroups of Legionella isolated.

In detail, of 92 water samples taken on board of ferries, 59 (64\%) were positive for the presence of Legionella; of these, 21 (36\%) were L. pneumophila sg 1 and 30 (51\%) L. pneumophila sgs $2-14$. In addition must be counted 8 (13\%) samples in which both $L$. pneumophila sg 1 and sgs $2-14$ were isolated. Of the 29 samples positive for the presence of Legionella pneumophila 1, 11 (39\%) contained a bacterial load of between $10^{3}$ and $10^{4} \mathrm{CFU} / \mathrm{L} ; 3$ (10\%) between $10^{4}-10^{5}$ and 14 (48\%), less than $10^{3} \mathrm{CFU} / \mathrm{L}$. A value greater than $10^{5} \mathrm{CFU} / \mathrm{L}$ was detected only in $1(3 \%)$ sample. According to Italian guidelines in force at the time of surveillance, this level is considered critical, even in the absence of clinical cases.

Of the 38 samples positive for the presence of Legionella pneumophila 2-14, 19 (50\%) contained a bacterial load of between $10^{3}$ and $10^{4} \mathrm{CFU} / \mathrm{L} ; 14$ (37\%) between $10^{4}-10^{5}$ and 5 (13\%) less than $10^{3} \mathrm{CFU} / \mathrm{L}$. No sample exceeded the value of $10^{5}$.

Of 136 water samples taken on board cruise ships, only 6 (4\%) were positive for the presence of Legionella; of these, 4 (67\%) were L. pneumophila sg 1 and 2 (33\%) L. pneumophila sgs $2-14$.

Of the 4 samples positive for the presence of Legionella pneumophila 1, 3 (75\%) contained a bacterial load of between $10^{3}$ and $10^{4} \mathrm{CFU} / \mathrm{L}$, and $1(25 \%)$ less than $10^{3} \mathrm{CFU} / \mathrm{L}$. Regarding L. pneumophila 2-14, both samples contained less than $10^{3}$ CFU/L. Distribution of Legionella positive samples according to serogroups and CFU/L isolated are presented in Figure $1(\mathrm{~d})$.

Legionella pneumophila 1 was isolated in 7 (70\%) ferries of the 10 examined, and in $2(33 \%)$ cruise ships of 6 examined.

Among the other microbial species simultaneously

Table 1. Distribution of samples taken on Ferries (a) and Cruise ships (b), positivity (\%) and serogroups identified. In the table the UCF/L range of L. pneumophila 1 and $2-14$ isolated also is indicated

\begin{tabular}{|c|c|c|c|c|c|c|}
\hline $\begin{array}{l}\text { Code ship given by } \\
\text { the Laboratory }\end{array}$ & $\begin{array}{l}\text { total number of } \\
\text { samples }\end{array}$ & samples of water & $\begin{array}{l}\text { samples of water } \\
\text { (\% POS) }\end{array}$ & $\begin{array}{l}\text { samples of air } \\
\text { (\% POS) }\end{array}$ & $\begin{array}{l}\text { samples of ice (\% } \\
\text { POS) }\end{array}$ & $\begin{array}{c}\text { Legionella Serogroups } \\
\text { (UCF/L range) }\end{array}$ \\
\hline \multicolumn{7}{|c|}{ (a) Ferries } \\
\hline$A$ & 7 & 6 & 0 & $1(0)$ & 0 & 0 \\
\hline B & 12 & 10 & $9(90)$ & $2(0)$ & 0 & $\begin{array}{c}1(500) \\
2-14(1800-80000)\end{array}$ \\
\hline$C$ & 14 & 10 & $7(70)$ & $4(0)$ & 0 & $\begin{array}{c}1(100-4000) \\
2-14(300-1500)\end{array}$ \\
\hline$D$ & 10 & 10 & $2(20)$ & 0 & 0 & $2-14(1500-2500)$ \\
\hline E & 16 & 12 & $4(33)$ & $4(0)$ & 0 & $1(100-900)$ \\
\hline $\mathrm{F}$ & 10 & 10 & $10(100)$ & 0 & 0 & $\begin{array}{c}1(200-3000) \\
2-14(300-40000)\end{array}$ \\
\hline G & 15 & 11 & $11(100)$ & $4(0)$ & 0 & $\begin{array}{c}1(100-30000) \\
2-14(2600-70000)\end{array}$ \\
\hline I & 8 & 6 & $2(33)$ & $2(0)$ & 0 & $2-14(200)$ \\
\hline $\mathrm{L}$ & 14 & 10 & $10(100)$ & $4(0)$ & 0 & $\begin{array}{c}1(1000-15000) \\
2-14(3000-25000)\end{array}$ \\
\hline Total & 116 & 92 & $59(64)$ & $24(0)$ & 0 & \\
\hline \multicolumn{7}{|c|}{ (b) Cruise ships } \\
\hline $\mathrm{A} 1$ & 33 & 25 & 0 & $6(0)$ & $2(0)$ & 0 \\
\hline B1 & 31 & 21 & 0 & $8(0)$ & $2(0)$ & 0 \\
\hline $\mathrm{C} 1$ & 28 & 20 & 0 & $8(0)$ & 0 & 0 \\
\hline D1 & 30 & 24 & $2(8)$ & $6(0)$ & 0 & $1(100-600)$ \\
\hline E1 & 27 & 21 & 4 (19) & $6(0)$ & 0 & $\begin{array}{c}1(200-5000) \\
2-14(400-500)\end{array}$ \\
\hline
\end{tabular}




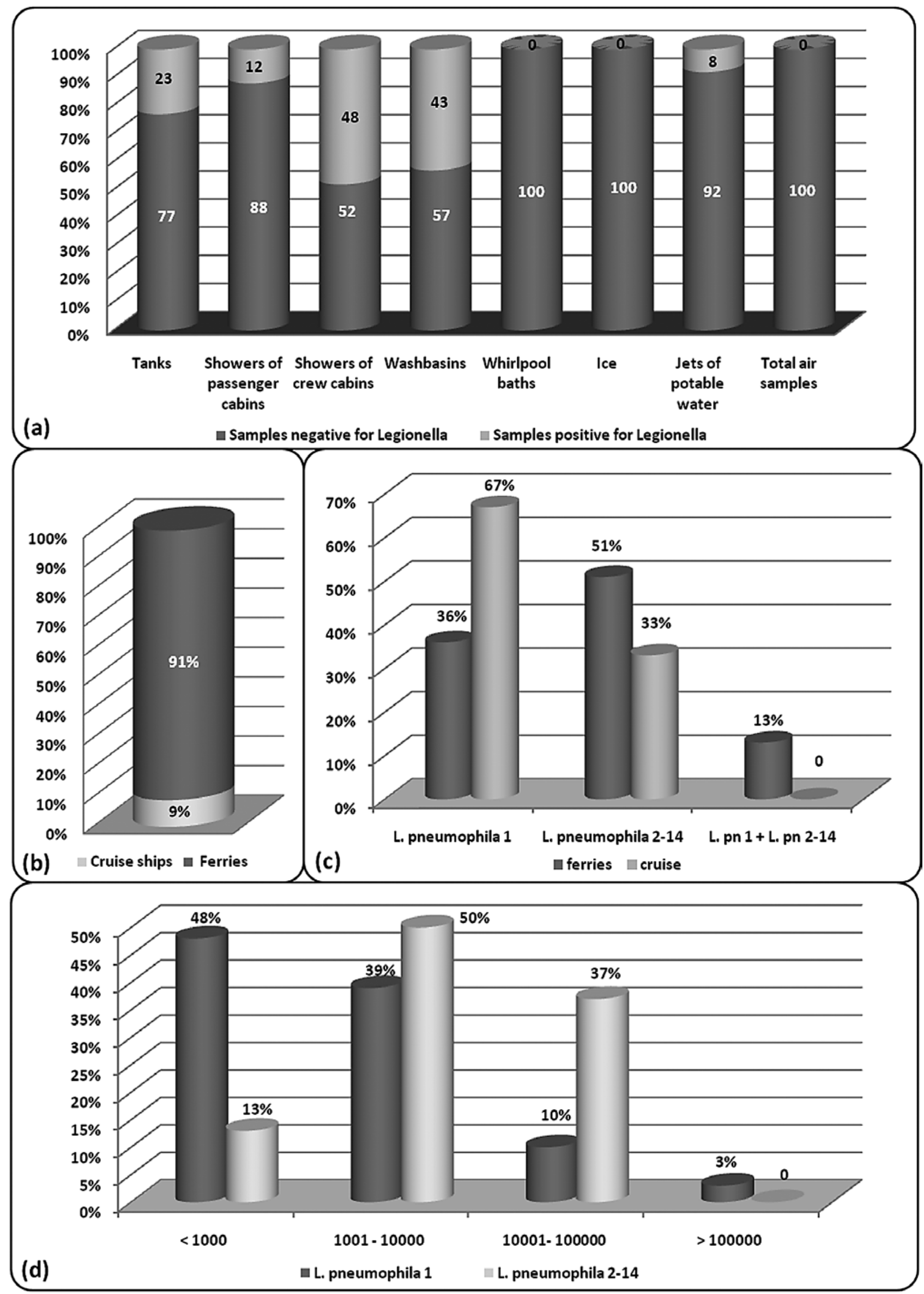

Graphic 1. (a) Percentage distribution samples pos/neg for Legionella vs source; (b) Percentage positive samples for Legionella: Cruise ships vs Ferries; (c) Percentage distribution of Legionella Serogroups isolated from ferries and cruise ships; (d) Percentage distribution of Legionella positive samples in according to UCF/L isolated 
recovered in the same sample, the most frequent was Pseudomonas spp. These data (not shown) are more interesting because the presence of Pseudomonadaceae is highly indicative for biofilm formation and the consequent induction of Legionella proliferation.
Regarding information collected via the questionnaires completed by the masters of both cruise ships and ferries, the results are summarized in Table 2 (ferries) and Table 3 (cruise ships).

Table 2. Data obtained from the questionnaires filled out by the commander of the ferries. The answers are faithfully reported

\begin{tabular}{|c|c|c|c|c|c|c|c|c|c|c|}
\hline $\begin{array}{l}\text { Code ship given by the } \\
\text { Laboratory }\end{array}$ & A & B & C & D & $\mathbf{E}$ & $\mathbf{F}$ & G & H & 1 & $\mathbf{L}$ \\
\hline Number of Crew & 11 & 37 & 12 & 22 & 20 & 11 & 13 & / & 14 & 12 \\
\hline Number crew cabins & 0 & 41 & 0 & 29 & 0 & 0 & 0 & 0 & 0 & 0 \\
\hline Number of passengers & I & 150 & I & 670 & - & I & I & I & / & I \\
\hline Number passenger cabins & 0 & 77 & 0 & 76 & 0 & 0 & 0 & 0 & 0 & 0 \\
\hline $\begin{array}{l}\text { Cases of infectious diseases } \\
\text { and clinical manifestations } \\
\text { registered on board ships }\end{array}$ & $\mathrm{N}$ & $\mathrm{N}$ & $\mathrm{N}$ & $\mathrm{N}$ & $\mathrm{N}$ & $\mathrm{N}$ & $\mathrm{N}$ & $\mathrm{N}$ & $\mathrm{N}$ & $\mathrm{N}$ \\
\hline $\begin{array}{l}\text { Chemical and microbiological } \\
\text { analyzes on water samples } \\
\text { (conformity) }\end{array}$ & $\begin{array}{c}\mathrm{Y} \\
\text { (Conform) }\end{array}$ & $\begin{array}{c}\mathrm{Y} \\
\text { (Conform) }\end{array}$ & $\begin{array}{c}\mathrm{Y} \\
\text { (Conform) }\end{array}$ & $\mathrm{N}$ & $\begin{array}{c}\mathrm{Y} \\
\text { (Conform) }\end{array}$ & $\begin{array}{c}\mathrm{Y} \\
\text { (Conform) }\end{array}$ & $\begin{array}{c}\mathrm{Y} \\
\text { (Conform) }\end{array}$ & $\begin{array}{c}\mathrm{Y} \\
\text { (Conform) }\end{array}$ & $\begin{array}{c}\mathrm{Y} \\
\text { (Conform) }\end{array}$ & $\begin{array}{c}\mathrm{Y} \\
\text { (Conform) }\end{array}$ \\
\hline $\begin{array}{l}\text { Typology of air conditioning } \\
\text { system on board }\end{array}$ & CENTR & CENTR & $\begin{array}{l}\text { CENTR } \\
\text { and IND }\end{array}$ & CENTR & CENTR & IND & IND & v & CENTR & $\begin{array}{l}\text { CENTR } \\
\text { and IND }\end{array}$ \\
\hline Number whirlpool baths & 0 & 0 & 0 & 0 & 0 & 0 & 0 & 0 & 0 & 0 \\
\hline Number of pools & 0 & 0 & 0 & 0 & 0 & 0 & 0 & 0 & 0 & 0 \\
\hline Pipe material & GALV & GALV & GALV & GALV & GALV & GALV & GALV & GALV & GALV & GALV \\
\hline $\begin{array}{l}\text { Maintenance and reclamation } \\
\text { waterworks (intervals) }\end{array}$ & $\mathrm{N}$ & Y (monthly) & $\mathrm{Y}$ (monthly) & Y (annual) & Y (annual) & $Y$ (monthly) & $\mathrm{Y}$ (monthly) & $\mathrm{N}$ & $\mathrm{N}$ & $Y$ (monthly) \\
\hline $\begin{array}{l}\text { Maintenance mode } \\
\text { waterworks }\end{array}$ & l & $\begin{array}{l}\text { Technico- } \\
\text { Mechanics }\end{array}$ & I & $\begin{array}{l}\text { Technico- } \\
\text { Mechanics }\end{array}$ & $\begin{array}{l}\text { Disinfection, } \\
\text { cleaning, } \\
\text { substitution } \\
\text { UV lamps }\end{array}$ & water flow & $\begin{array}{l}\text { Disinfection, } \\
\text { Cleaning, } \\
\text { Substitution } \\
\text { UV lamps }\end{array}$ & / & / & I \\
\hline $\begin{array}{l}\text { Presence of ultraviolet ray } \\
\text { lamps }\end{array}$ & $\mathrm{Y}$ & / & Y & $\mathrm{N}$ & $\mathrm{Y}$ & $\mathrm{N}$ & $\mathrm{Y}$ & $\mathrm{Y}$ & $\mathrm{N}$ & $\mathrm{Y}$ \\
\hline $\begin{array}{l}\text { Maintenance potable water } \\
\text { tanks (intervals) }\end{array}$ & $\mathrm{N}$ & $\mathrm{N}$ & $\mathrm{N}$ & $\begin{array}{l}\mathrm{Y} \text { (half- } \\
\text { yearly) }\end{array}$ & $\mathrm{N}$ & $\mathrm{N}$ & $\mathrm{N}$ & $\mathrm{N}$ & $\mathrm{N}$ & $\mathrm{N}$ \\
\hline $\begin{array}{l}\text { Presence of evaporation } \\
\text { towers, aerators and } \\
\text { humidifiers (intervals) }\end{array}$ & $\begin{array}{c}\mathrm{Y} \\
\text { (fortnightly) }\end{array}$ & Y (weekly) & I & - & $\mathrm{N}$ & $Y$ (monthly) & Y (quaterly) & $\mathrm{N}$ & / & I \\
\hline Maintenance mode & SAN & SAN & / & - & / & Water flow & Cleaning & I & / & / \\
\hline
\end{tabular}

Legend. CENTR: Centralized; DISINF: Disinfection; IND: independent; GALV Galvanized steel; SAN: sanification; Y: Yes; N: No.

Table 3. Data obtained from the questionnaires filled out by the commander of the cruise ships. The answers are faithfully reported

\begin{tabular}{|c|c|c|c|c|c|c|}
\hline $\begin{array}{l}\text { Code ship given by the } \\
\text { Laboratory }\end{array}$ & A1 & B1 & C1 & D1 & E1 & F1 \\
\hline Number of Crew & 775 & 509 & 577 & 882 & 394 & 1002 \\
\hline Number crew cabins & 474 & 308 & 353 & 508 & 207 & 250 \\
\hline Number of passengers & 1577 & 1220 & 884 & 2146 & 937 & 2466 \\
\hline Number passenger cabins & 964 & 513 & 654 & 1057 & 410 & 1080 \\
\hline $\begin{array}{l}\text { Cases of infectious diseases and } \\
\text { clinical manifestations registered } \\
\text { on board ships }\end{array}$ & $\mathrm{N}$ & Y (Fever) & Y (varicella) & $\begin{array}{c}\mathrm{Y} \\
\text { (Fever) }\end{array}$ & $\mathrm{N}$ & $\mathrm{N}$ \\
\hline $\begin{array}{l}\text { Chemical and microbiological } \\
\text { analyzes on water samples } \\
\text { (conformity) }\end{array}$ & $\begin{array}{c}\mathrm{Y} \\
\text { (Conform) }\end{array}$ & $\begin{array}{c}\mathrm{Y} \\
\text { (Conform) }\end{array}$ & Y (Conform) & $\begin{array}{c}\mathrm{Y} \\
\text { (Conform) }\end{array}$ & $\begin{array}{c}\mathrm{Y} \\
\text { (Conform) }\end{array}$ & $\begin{array}{c}\mathrm{Y} \\
\text { (Conform) }\end{array}$ \\
\hline $\begin{array}{l}\text { Typology of air conditioning } \\
\text { system on board }\end{array}$ & CENTR & CENTR & CENTR & IND & CENTR & CENTR and IND \\
\hline
\end{tabular}


Table 3. Data obtained from the questionnaires filled out by the commander of the cruise ships. The answers are faithfully reported

\begin{tabular}{|c|c|c|c|c|c|c|}
\hline $\begin{array}{l}\text { Code ship given by the } \\
\text { Laboratory }\end{array}$ & $\mathbf{A 1}$ & B1 & C1 & D1 & E1 & $\mathbf{F 1}$ \\
\hline $\begin{array}{l}\text { Maintenance of the air- } \\
\text { conditioning system (intervals) }\end{array}$ & $\begin{array}{c}\mathrm{Y} \\
\text { (monthly) }\end{array}$ & $\mathrm{Y}$ (monthly) & $\mathrm{Y}$ (monthly) & $\begin{array}{c}\mathrm{Y} \\
\text { (monthly) }\end{array}$ & $\mathrm{Y}$ (monthly) & $\mathrm{Y}$ (monthly) \\
\hline Number whirlpool baths & 5 & 3 & 4 & 4 & 3 & 3 \\
\hline $\begin{array}{l}\text { Maintenance of whirlpool baths } \\
\text { (intervals) }\end{array}$ & Y (daily/monthly) & $\begin{array}{c}\mathrm{Y} \\
\text { (daily) }\end{array}$ & Y (daily) & $\begin{array}{l}\text { Y (daily/monthly/ } \\
\text { half-yearly) }\end{array}$ & $\begin{array}{l}\text { Y (daily/monthly/ } \\
\text { half-yearly) }\end{array}$ & $\begin{array}{c}\mathrm{Y} \\
\text { (daily) }\end{array}$ \\
\hline Number of pools & 3 & 3 & 2 & 4 & 2 & 3 \\
\hline $\begin{array}{l}\text { Maintenance of pools } \\
\text { (intervals) }\end{array}$ & $\begin{array}{l}\text { Y (daily/monthly/ } \\
\text { yearly) }\end{array}$ & $\begin{array}{c}\mathrm{Y} \\
\text { (daily) }\end{array}$ & $Y$ (daily) & $\begin{array}{c}\mathrm{Y} \\
\text { (daily) }\end{array}$ & $\begin{array}{c}\mathrm{Y} \\
\text { (daily) }\end{array}$ & $\begin{array}{c}\mathrm{Y} \\
\text { (daily) }\end{array}$ \\
\hline Maintenance mode pools & $\begin{array}{c}\text { Change } \\
\text { filters; Hyper- } \\
\text { halogenation tanks }\end{array}$ & Hyperchlorination & $\begin{array}{l}\text { Cleaning and } \\
\text { Chlorination }\end{array}$ & $\begin{array}{c}\text { Cleaning and } \\
\text { hyperchlorination }\end{array}$ & Hyperchlorination & $\begin{array}{l}\text { Emptying and } \\
\text { sanification }\end{array}$ \\
\hline $\begin{array}{l}\text { Maintenance and reclamation } \\
\text { waterworks (intervals) }\end{array}$ & $\begin{array}{c}\text { Y } \\
\text { (for each load, } \\
\text { daily, monthly) }\end{array}$ & Y (half-yearly) & $\mathrm{N}$ & Y (half-yearly) & $\begin{array}{c}\mathrm{Y} \\
\text { (weekly/quaterly) }\end{array}$ & Y (fortnightly) \\
\hline Maintenance mode waterworks & $\begin{array}{l}\text { Analyzers control } \\
\text { and halogenated } \\
\text { residual values }\end{array}$ & $\begin{array}{c}\text { Visual } \\
\text { inspection }\end{array}$ & / & $\begin{array}{l}\text { Cleaning, } \\
\text { Hyperchlorination } \\
\text { of silt }\end{array}$ & Hyperchlorination & SAN \\
\hline $\begin{array}{l}\text { Presence and number of } \\
\text { ultraviolet ray lamps }\end{array}$ & $\mathrm{Y}$ & $\mathrm{N}$ & $\mathrm{N}$ & Y & $\mathrm{N}$ & $\mathrm{N}$ \\
\hline $\begin{array}{l}\text { Maintenance potable water } \\
\text { tanks (intervals) }\end{array}$ & $\begin{array}{c}\mathrm{Y} \\
\text { (half-yearly) }\end{array}$ & Y (half-yearly) & Y (half-yearly) & Y (annual) & Y (half-yearly) & $\begin{array}{c}\mathrm{Y} \\
\text { (half-yearly) }\end{array}$ \\
\hline $\begin{array}{l}\text { Maintenance mode of potable } \\
\text { water tanks }\end{array}$ & / & Visual inspection & DISINF & $\begin{array}{c}\text { Cleaning and } \\
\text { hyperchlorination }\end{array}$ & Hyperchlorination & $\begin{array}{l}\text { Emptying and } \\
\text { sanification }\end{array}$ \\
\hline $\begin{array}{l}\text { Presence of evaporation towers, } \\
\text { aerators and humidifiers } \\
\text { (intervals) }\end{array}$ & $\mathrm{N}$ & $\mathrm{N}$ & Y (half-yearly) & $\begin{array}{l}\text { Y (weekly/ } \\
\text { quaterly) }\end{array}$ & Y (weekly) & Y (weekly) \\
\hline Maintenance mode & / & / & $\begin{array}{l}\text { Cleaning and } \\
\text { calibration }\end{array}$ & $\begin{array}{l}\text { Visual inspection } \\
\text { and replacement }\end{array}$ & $\begin{array}{l}\text { Cleaning and } \\
\text { Chlorination }\end{array}$ & SAN \\
\hline
\end{tabular}

Legend. CENTR: Centralized; DISINF: Disinfection; IND: independent; SAN: sanification. Y Yes; N No.

\section{CONCLUSIOINS AND DISCUSSION}

The presented study further confirms data from previous studies showing that both hot and cold water distribution systems on board ferries can be more easily colonized by Legionella spp. at high concentrations, compared to cruise ships. Similar results were previously obtained by Azara $e t$ al. in a study performed on 2 cruise ships and 7 ferries docked at seaports in northern Sardinia in 2004. Data obtained from these studies showed that 6/7 (86\%) ferries were positive, $38 / 90(42 \%)$ of the water samples were contaminated, and $77.8 \%$ contained $\geq 10^{4} \mathrm{CFU} / \mathrm{L}$ [29]. Another Italian study, performed by Negretto et al. at the port of Venice (data unpublished) in 2010, further confirms the data of the current study, and shows that ferries present more high risks of Legionella contamination, compared to cruise ships. Similarly, a previous survey carried out by Goutziana et al. in 33 water tanks on yachts in Athens, showed that approximately $40 \%$ were positive for Legionella spp. [30]. The results obtained in the presented study further confirm the frequent and high $L$. pneumophila contamination in water distribution systems of ferries, and underlnie the need for adopting more specific preventive measures. This was also recently and further confirmed by Mouchtouri and Rudge [31]. Cayla JA et al, reported 2 cases of Legionellosis that occurred in two mechanics working on a cargo ship under repair [32].

The biggest problems lie with the ferries where the high risk of Legionella colonization is mainly caused to their old and always non-optimal conditions of most of these vessels (Tab. 2). In addition, the limited number of crew members and their particular turnover hamper the correct surveillance of the water safety plan. In some cases, the water tanks are not easily accessible due to the small size of the vessels and, consequently, a less accurate sanification may induce the formation of biofilm that represents the main substrate for the growth of both Legionella spp. and other pathogens. Finally, the showers and other washing facilities not continuously used, unlike on board the cruise ships, represent a further cause of contamination.

In 2005, the European Commission funded the SHIPSAN project which aims at assessing the usefulness of an EU ship sanitation programme and coordinated action for the control of communicable diseases in cruise ships and ferries [33]. The European Manual for Hygiene Standards and Communicable Diseases, edited by the European ShipSan trainer partnership, contains detailed guidelines to prevent and control legionellosis on passenger ships [34]. However, in the opinion of the authors of this study, it would be advisable to edit a water sampling plan more specific for the ferries in 
order to consider their particular requirements. This plan should oversee all water outputs, including showers and sinks. During sanitation practices, the water tanks could be subjected to enzymatic treatment for preventing biofilm formation. In the ferries where the personnel is always subjected to mobility and turnover from a vessel to another, according to seasonal needs and itineraries, it is very difficult to identify a unique and competent person who could be responsible for supervision and health safety, able to control the correct performance of the procedures in compliance with the safety water plan adopted to avoid biofilm formation and Legionella contamination.

A specialized external inspection team should be appointed and able to check compliance with specific procedures adopted by each ship. The inspectors should periodically conduct a reassessment of the sites at high risk of contamination in order to evaluate the need to implement further precautions able to control all identified risk from Legionella. The team should be composed of members with specific skills (e.g. a microbiologist, environmental health officer or water engineer with specific expertise). These additional control measures could contribute to the maintainment of protection at satisfactory levels, comparable to that of cruise ships. Moreover, to evaluate the potential contamination of Legionella in ships (both cruises and ferries), it could be useful to apply georeferential statistical analysis to assess the possible sources of dispersion and, consequently, the risk of exposure for both crew and passengers [35].

\section{Authors' contributions}

Prof. Dr. Pasqualina Lagana made substantial contributions to the conception and design analysis and acquisition of data, carried out the analysis in the laboratory for the detection of Legionella, and was involved in drafting the manuscript. Dr. Maria Elsa Gambuzza, an expert in the field of maritime health, also involved in drafting the manuscript. Prof. Dr. Santi Delia, an expert in the field of Legionella, made substantial contributions to the conception and design, analysis and interpretation of data. He, too, was involved in critically revising the manuscript for important intellectual content, and in the final approval of the version to be submitted.

\section{REFERENCES}

1. Passenger transport statistics. Data from July and October 2014. Most recent data: Further Eurostat information, Main tables and Database. Planned article update: October 2015. http://ec.europa.eu/eurostat/ statistics-explained/index.php/Passenger_transport_statistics

2. http://www.who.int/ith/mode_of_travel/sea_travel/en/

3. Borges V, Nunes A, Sampaio DA, Vieira L, Machado J, Simões MJ, et al. Legionella pneumophila strain associated with the first evidence of person-to-person transmission of Legionnaires' disease: a unique mosaic genetic backbone. Sci Rep. 2016; 6:26261.

4. Centers for Disease Control and Prevention (CDC). Cruise-ship-associated Legionnaires disease, November 2003-May 2004. MMWR Morb Mortal Wkly Rep. 2005; 54(45):1153-5

5. Ahlén C, Aas M, Nor A, Wetteland PI, Johansen H, Sørbø T et al. Legionella pneumophila in Norwegian naval vessels. Tidsskr Nor Laegeforen. 2013; 133(14):1445-8.

6. de Jong B, Payne Hallström L, Robesyn E, Ursut D, Zucs P, et al. Travelassociated Legionnaires' disease in Europe, 2010. Euro Surveill. 2013; 18(23). pii: 20498.

7. Guyard C, Low DE. Legionella infections and travel associated legionellosis. Travel Med Infect Dis. 2011; 9(4):176-86.

8. Regan CM, McCann B, Syed Q, Christie P, Joseph C, Colligan J, et al. Outbreak of Legionnaires' disease on a cruise ship: lessons for international surveillance and control. Commun Dis Public Health. 2003; 6(2):152-6.
9. Castellani Pastoris M, Lo Monaco R, Goldoni P, Mentore B, Balestra $\mathrm{G}$, Ciceroni L, et al. Legionnaires' disease on a cruise ship linked to the water supply system: clinical and public health implications. Clin Infect Dis. 1999; 28(1):33-8.

10. Rowbotham TJ. Legionellosis associated with ships: 1977 to 1997. Commun Dis Public Health. 1998; 1(3):146-51.

11. Jernigan DB, Hofmann J, Cetron MS, Genese CA, Nuorti JP, Fields BS, et al. Outbreak of Legionnaires' disease among cruise ship passengers exposed to a contaminated whirlpool spa. Lancet. 1996; 347(9000):4949.

12. Sedgwick J, Joseph C, Chandrakumar M, Harrison T, Lee J, de Jong B. Outbreak of respiratory infection on a cruise ship. Euro Surveill. 2007; 12(8): E070809.1.

13. Beyrer K, Lai S, Dreesman J, Lee JV, Joseph C, Harrison T, et al. Legionnaires' disease outbreak associated with a cruise liner, August 2003: epidemiological and microbiological findings. Epidemiol Infect. 2007; 135(5):802-10.

14. Kobayashi A, Yamamoto Y, Chou S, Hashimoto S. Severe Legionella pneumophila pneumonia associated with the public bath on a cruise ship in Japan. J Anesth. 2004; 18(2): 129-31.

15. Kruse EB, Wehner A, Wisplinghoff $H$. Prevalence and distribution of Legionella spp in potable water systems in Germany, risk factors associated with contamination, and effectiveness of thermal disinfection American Journal of Infection Control; 2015; 44(4): 470-474.

16. Zbikowska E, Kletkiewicz H, Walczak M, Burkowska A. Coexistence of Legionella pneumophila Bacteria and Free-Living Amoebae in Lakes Serving as a Cooling System of a Power Plant. Water Air Soil Pollut. 2014; 225: 2066.

17. Aaberge IS. Legionella bacteria in water supply systems. Tidsskr Nor Laegeforen. 2013; 133(14):1426.

18. Stojek N, Dutkiewicz J. Legionella and other gram-negative bacteria in potable water from various rural and urban sources. Ann Agric Environ Med. 2006; 13(2):323-35.

19. Laganà $P$, Caruso G, Piccione D, Pino R, Gioffrè ME, Delia S. Legionella spp., amoebae and not-fermenting Gram negative bacteria in an Italian university hospital water system Ann Agric Environ Med. 2014; 21(3): 489-493.

20. Lau R, Maqsood S, Harte D, Caughley B, Deacon R. Prevalence of Legionella strains in cooling towers and legionellosis cases in New Zealand. J Environ Health 2013; 75(6):82-9.

21. Kura F, Amemura-Maekawa J, Yagita K, Endo T, Ikeno M, Tsuji H et al. Outbreak of Legionnaires' disease on a cruise ship linked to spa-bath filter stones contaminated with Legionella pneumophila serogroup 5. Watanabe H. Epidemiol. Infect. 2006; 134(2):385-91.

22. Benkel DH, McClure EM, Woolard D, Rullan JV, Miller GB Jr, Jenkins SR et al. Outbreak of Legionnaires' disease associated with a display whirlpool spa. Int J Epidemiol. 2000; 29(6):1092-8.

23. Gambuzza ME. Environmental health and hygiene on the ships: biofilm control strategies. Shipsan Newletter. 2013; 5. Available from: http://www.shipsan.eu/Home/Newsletter/TabId/113/ArtMID/542/ ArticleID/53/EU-SHIPSAN-ACT-JA---Newsletter-Issue-5.aspx

24. Stewart CR, Muthye V, Nicholas P, Cianciotto P. Legionella pneumophila persists within biofilms formed by Klebsiella pneumoniae, Flavobacterium sp., and Pseudomonas fluorescens under dynamic flow conditions. Plos One. 2012; 7(11): e50560.

25. http://www.shipsan.eu/Portals/0/docs/SHIPSAN_Manual.pdf

26. Italian Guidelines for the prevention and control of legionellosis. Gazzetta Ufficiale della Repubblica Italiana, 2000; No.103, 5 May.

27. Montagna MT, Cristina ML, De Giglio O, Spagnolo AM, Napoli C, Cannova L, et al. Serological and molecular identification of Legionella spp in water and surrounding air samples in Italian healthcare facilities. Environ Res. 2016; 146(4): 47-50

28. Montagna MT, De Giglio O, Napoli C, Cannova L, Cristina ML, Deriu MG, et al. Legionella spp. contamination in indoor air: preliminary results of an Italian multicenter study. Epidemiol Prev 2014; 38(6) Suppl 2: 62-65.

29. Azara A, Piana A, Sotgiu G, Dettori M, Deriu MG, Masia MD et al. Prevalence study of Legionella spp. contamination in ferries and cruise ships. BMC Public Health. 2006; 6:100.

30. Goutziana G, Mouchtouri VA, Karanika M, Kavagias A, Stathakis NE, Gourgoulianis K et al. Legionella species colonization of water distribution systems, pools and air conditioning systems in cruise ships and ferries. BMC Public Health BMC Public Health 2008; 24(8):390.

31. Mouchtouri VA, Rudge JW. Legionnaires' Disease in Hotels and Passenger Ships: A Systematic Review of Evidence, Sources, and Contributing Factors. J Trav Med. 2015; 22(5): 325-37.

32. Caylà JA, Maldonado R, González J, Pellicer T, Ferrer D, Pelaz C et al. Legionellosis study group. A small outbreak of Legionnaires' disease in a cargo ship under repair. Eur Respir J. 2001; 17(6):1322-7.

33. http://www.eu-shipsan.gr/webcite

34. http://www.shipsan.eu/KeyResources.aspx

35. Laganà $\mathrm{P}$, Moscato U, Poscia A, La Milia D, Boccia S, Avventuroso E et al. The Geostatistics, tool applied to the distribution of Legionella pneumophila in a hospital water system. Ann Agric Environ Med. 2015; 22(4):749-754. 